\title{
THE RELATIONSHIP BETWEEN E-GOVERNMENT AND CORRUPTION: AN EMPIRICAL ANALYSIS USING PANEL DATA
}

\author{
Gamze ÖZ YALAMAN ${ }^{1}$
}

\begin{abstract}
E-Government can be defined as the use of information and communication technologies by the government in order to work more effectively share information and deliver better services to the public. It is known that e-government applications strengthen accountability, increase transparency and efficiency of the government. Corruption is a highly complex phenomenon which rooted in bureaucratic and political institutions and their effects vary from country to country. Given the socio-economic conditions, political and institutional infrastructure and other factors, it is difficult to make a generally accepted definition of corruption, but in its narrowest definition, abuse of public power for private interests. It is known that corruption creates negative effects on the economic growth of the countries, tax structure, quality of public services, and the rule of law.In this context, the paper tests the effects of e-government on corruption via panel data analysis by using a large data set consisting of 193 countries belonging to the period 2003-2017. While examining the relationship between e-government and corruption, many control variables that may affect this relationship were taken into consideration. The empirical findings of the study show that e-government has a statistically significant and negative effect on corruption. Consistent with the common literature, the findings of the study emphasize that the increase in e-government applications reduces corruption.
\end{abstract}

Keywords: E-government, corruption, panel data, internet usage

JEL Code: D73, H11, O57.

\section{Introduction}

With the development of the 1990s, the Internet has become an indispensable element of individuals and states. It is seen that states have been using the potential of the internet in order to improve and perfect the management processes since the mid-1990s. This situation led to the emergence of e-government concept.

According to the United Nations (2002), e-government can be defined as the use of information and communication technologies in order to provide state services more effectively and efficiently to citizens and businesses. As it can be seen from the definition, it is aimed to provide efficient, effective and transparent services through e-government applications. In addition, it is thought that e-government will strengthen relations with enterprises and sectors, strengthen citizens because of easy access to information and thus increase the confidence in the state and provide a more effective citizen-state relationship. As a result of these positive aspects, less corruption, increased transparency, greater convenience in obtaining services, increased public revenues and / or decreasing expenditures are expected (Panzardi et al., 2002: 2).

Corruption is a highly complex phenomenon whose roots are deeply rooted in bureaucratic and political institutions, and whose effects vary from country to country and can be described as the most straightforward definition of the abuse of public power for private interests (World

\footnotetext{
1 Asst. Prof. Dr., Eskisehir Osmangazi University, Department of Public Finance, gamze.ozyalaman@gmail.com
} 
Bank, 1997: 8). In theory, the impact of E-government practices on corruption can be positive or negative (Bhatnagar, 2003: 30; Elbahnasawy, 2014: 114). However, the number of empirical studies testing the impact of e-government practices on corruption is insufficient (Elbahnasawy, 2014: 114; Kim et al., 2009: 42; Andersen, 2009: 209; Nam, 2018: 281). In this context, the effects of e-government on corruption are tested using a large data set consisting of 193 countries belonging to the period 2003-2017 by using panel data analysis. While examining the relationship between e-government and corruption, control variables that may affect this relationship were also taken into consideration. The empirical findings of the study show that e-government has a statistically significant and negative effect on corruption.

\section{Literature Review}

Several commonly used definitions of e-government are as follows. According to the United Nations (2002), e-government can be defined as the use of information and communication technologies in order to provide state services more effectively and efficiently to citizens and businesses.

According to the World Bank definition, e-government is a system that uses state-owned information and communication technologies to promote the empowerment of citizens, improve service delivery, strengthen accountability, increase transparency, or transform relations with citizens, the private sector and / or other government institutions in order to increase the efficiency of the state.

West (2004) describes the e-government as the state's provision of information and services in the internet or other digital media.

According to Palvia and Sharma (2007), e-government is a general term for web-based services of institutions at local, state and federal levels.

As it can be seen from the definitions, it is aimed to provide efficient, effective and transparent services through e-government applications. In empirical studies, it is seen that e-government applications provide benefits such as less corruption, greater transparency, greater convenience in obtaining services, increased public revenues and / or decreasing expenditures, and this situation can positively affect the trust in the state (Furlong, 2005: 61-67; Welch et al., 2005; 386-387; Tolbert \& Mossberger, 2006: 362-363).

The negative effects of corruption, which can be defined as abuse of public power for private interests, may vary from country to country and the determinants of corruption have been examined in different studies (Serra, 2006: 225; Dimant \& Tosato, 2018: 344-345).

A few empirical studies examining the impact of e-government practices on corruption are available in the literature. For example, Shim and Eom (2008) stated that e-government has a positive effect on corruption. Andersen (2009) explores the relationship between e-government and corruption in 149 countries for 1996 and 2006. The findings of the study show that the increase in e-government use reduces corruption. Krishnan, Teo and Lim (2013) state that the level of corruption in countries will decrease as e-government applications mature. Elbahnasawy (2014) reveals that e-government is an important tool in reducing corruption by using a data set covering 160 countries and 1995-2009 years. Nam (2018) examines the relationship between e-government and corruption by using cross-sectional data and he states that political, economic and cultural 
characteristics are important factors that could limit the e-government's mitigation effect on corruption. For example, the anti-corruption effect of the e-government is significantly reduced in cultures where individuals perceive an unequal power distribution and feel uncomfortable with uncertainty. Another important finding is that more democratic countries are able to control corruption effectively.

The literature introduce many different control variables which have significant effect on the relationship between e-government and corruption such as internet services, human capital, telecommunications, inflation, public expenditures, tax revenues, internet users, internet security, per capita national income, public activity, political stability, the rule of law, accountability (Braun \& Di Tella, 2004: 77; Serra, 2006: 225; Elbahnasawy \& Revier, 2012: 311; Elbahnasawy, 2014: 119).

In this context, the paper investigates the effects of e-government on corruption by taking into account many control variables that may affect this relationship.

\section{Data, Model and Empirical Resuts}

In this study, the effects of e-government on corruption are tested by using panel data regression with a large data set consisting of 193 countries belonging to 2003-2017 period. The data were obtained from the World Bank and the United Nations. The predicted regression model and the control variables are displayed in equation 1 and equation 2, respectively.

Corruption $_{i t}=\beta_{0}+B_{1} E-$ Government $_{i t}+\sum_{k=2}^{n} \beta_{k}$ ControlVariables $_{i t}+\varepsilon_{i t}$

$\sum_{\mathrm{k}=2}^{\mathrm{n}} \beta_{\mathrm{k}}$ ControlVariables $_{\mathrm{it}}=\mathrm{B}_{2} \quad$ InternetServices $\mathrm{it}^{+} \quad \mathrm{B}_{3} \quad$ HumanCapital $_{\mathrm{it}}+\mathrm{B}_{4}$ Telecommunication ${ }_{i t}+B_{5}$ Inflationn $_{i t}+B_{6}$ GovernmentExpenditures $_{i t}+B_{7}$ TaxRevenue $_{i t}+B_{8}$ InternetUsers ${ }_{i t}+B_{9}$ InternetSecurity $y_{i t}+B_{10}$ GDPpercapita ${ }_{i t}+B_{11}$ GovernmentEffectiveness $s_{i t}$ $+\mathrm{B}_{12}$ PoliticStability ${ }_{i t}+\mathrm{B}_{13}$ RuleofLaw ${ }_{i t}+\mathrm{B}_{14}$ VoiceandAccountabilityit

The control variables are Internet Services, Human Capital, Telecommunications, Inflation, Government Expenditures, Tax Revenues, Internet Users, Internet Security, GDP Per Capita, Government Effectiveness, Political Stability, Rule of Law, Voice and Accountability. In this context, 8 different models were estimated. The empirical findings in Table 1 show that e-government has a statistically significant and negative effect on corruption without changing depending on different control variables.For estimating the coefficients of a single equation 1 , the random effect estimator is used following by the existence literature. However, the diagnostic tests indicate the presence of heteroscedasticity and autocorrelation for all models. In order to deal withthese problems, GLS estimator is used (Baltagi, 2008: 14-15). The results are robust and indicate a negative relationship between e-government and corruption. 


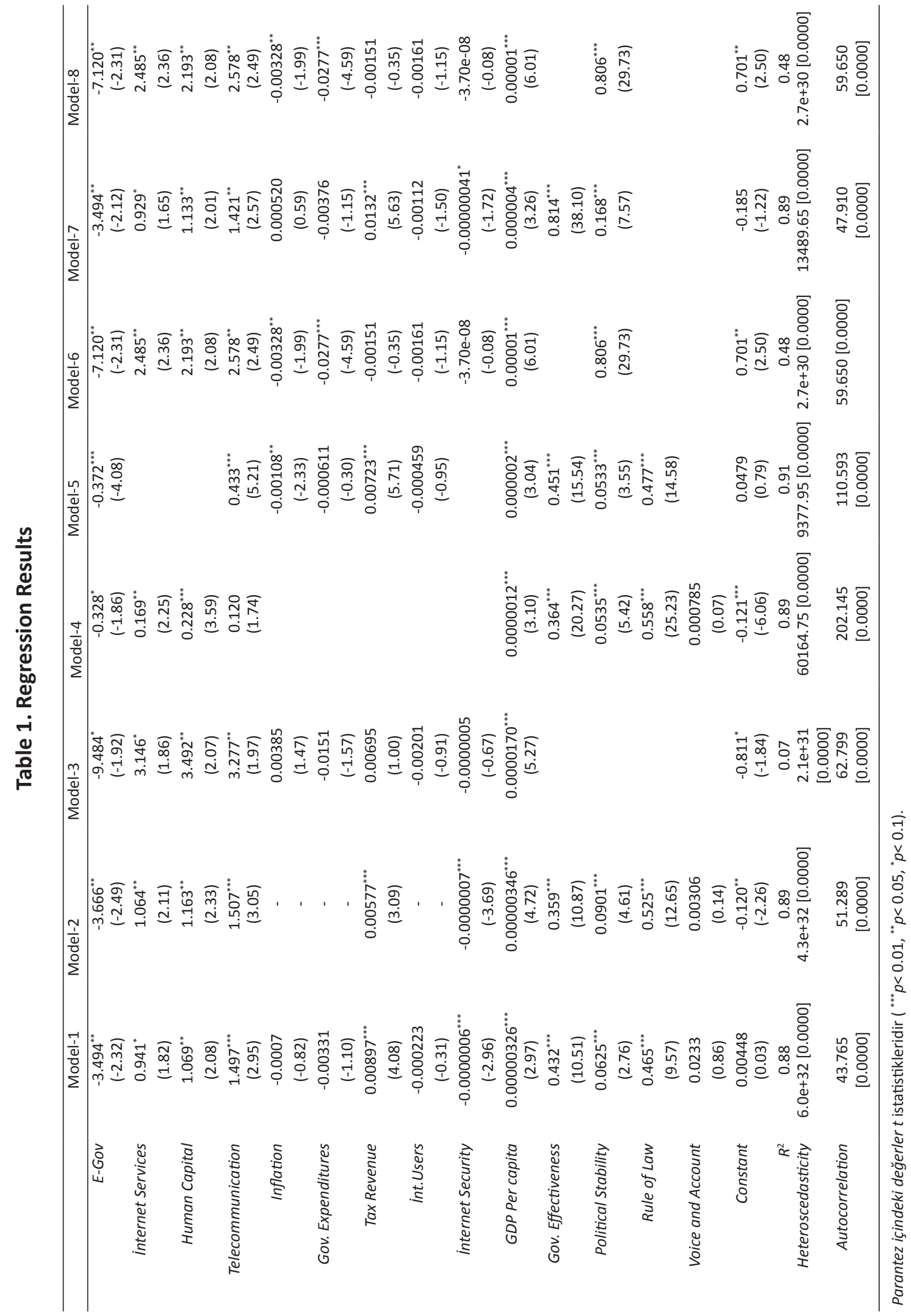




\section{Conclusion}

E-Government is a web based system aiming to provide the right information to the citizen on a common point in electronic environment in a secure, uninterrupted and fast way by considering the user needs of public services. With the increase in e-government applications, it is known that the accountability is strengthened, the transparency and the efficiency of the state increase.

It is very difficult to make a generally accepted definition of corruption, and different definitions of corruption are made by international organizations. A generally accepted definition of corruption is made by the World Bank as abuse of public power for private interests. The effects of corruption are a highly complex phenomenon that changes from country to country. It is known that corruption creates negativities on the macroeconomic and administrative indicators of countries.

In this context, the paper tests the effects of e-government on corruption by using panel data analysis with a large data set consisting of 193 countries belonging to the period 2003-2017. While examining the relationship between e-government and corruption, control variables that may affect this relationship were also taken into consideration. The empirical findings show that e-government has a statistically significant and negative effect on corruption. In accordance with the literature, the findings of the study show that the increase in e-government applications reduces corruption.

\section{References}

Andersen, T. B. (2009). "E-Government as an anti-corruption strategy", Information Economics and Policy, 21(3), 201-210.

Baltagi, B. (2008). Econometric analysis of panel data, John Wiley \& Sons.

Bhatnagar S. (2003). E-government and access to information, United Nations Global Corruption Report 2003. http://unpan1.un.org/intradoc/groups/public/documents/APCITY/ UNPAN008435.pdf

Birleşmiş Milletler (2002). Benchmarking E-government: A Global Perspectivehttps:// publicadministration.un.org/egovkb/Portals/egovkb/Documents/un/English.pdf

Braun, M., \& Di Tella, R. (2004). "Inflation, inflation variability, and corruption", Economics \& Politics, 16(1), 77-100.

Dimant, E., \& Tosato, G. (2018). "Causes and effects of corruption: what has past decade's empirical research taught us? A survey". Journal of Economic Surveys, 32(2), 335-356.

Dünya Bankası (1997). Helping Countries Combat Corruption, The Role of the World Bank, http:// www1.worldbank.org/publicsector/anticorrupt/corruptn/corrptn.pdf

Elbahnasawy, N. G. (2014). "E-government, internet adoption, and corruption: an empirical investigation", World Development, 57, 114-126.

Elbahnasawy, N. G., \& Revier, C. F. (2012). "The determinants of corruption: Cross-countrypanel-data analysis", The Developing Economies, 50(4), 311-333. 
Furlong S. Vitro Robert (2005). E-government in Canada: Building public trust through citizencentric governance, The knowledge economy in development: Perspectives for effective partnerships, 2005Washington, DCInter-American Development Bank.

Kim, S., Kim, H. J., \& Lee, H. (2009). "An institutional analysis of an e-government system for anti-corruption: The case of OPEN", Government Information Quarterly, 26(1), 42-50.

Krishnan, S., Teo, T. S., \& Lim, V. K. (2013). “Examining the relationships among e-government maturity, corruption, economic prosperity and environmental degradation: A cross-country analysis", Information \& Management, 50(8), 638-649.

Nam, T. (2018). "Examining the anti-corruption effect of e-government and the moderating effect of national culture: A cross-country study", Government Information Quarterly, 35(2), 273-282.

Palvia, S. C. J., \& Sharma, S. S. (2007, December). E-government and e-governance: definitions/ domain framework and status around the world. In International Conference on E-governance (pp. 1-12).

Panzardi, R., Calcopietro, C., \& Ivanovic, E. F. (2002). New-economy sector study electronic government and governance: lessons for Argentina. New-economy sector study: electronic government and governance-lessons from Argentina Retrieved from http://documents. worldbank. org/ curated/en/527061468769894044/pdf/266390WPOE1Gov1gentina1Final1Report. pdf.

Serra, D. (2006). "Empirical determinants of corruption: A sensitivity analysis", Public Choice, 126(1-2), 225-256.

Shim, D. C., \& Eom, T. H. (2008). "E-government and anti-corruption: Empirical analysis of international data", Intl Journal of Public Administration, 31(3), 298-316.

Tolbert, C. J., \& Mossberger, K. (2006). "The effects of e-government on trust and confidence in government", Public administration review, 66(3), 354-369.

Welch, E. W., Hinnant, C. C., \& Moon, M. J. (2004). “Linking citizen satisfaction with e-government and trust in government", Journal of public administration research and theory, 15(3), 371-391.

West, D. M. (2004). "E-government and the transformation of service delivery and citizen attitudes", Public administration review, 64(1), 15-27.

World Bank. 2002. The e-government handbook for developing countries: The e-government handbook for developing countries: a project of InfoDev and the Center for Democracy and Technology (English). infoDev. Washington, DC: World Bank. 